\title{
チャ及び近縁ツバキ属植物における木部樹液中のアミノ酸組成
}

\author{
独立行政法人 農業技術研究機構 花き研究所* \\ 岡野邦夫 \\ 独立行政法人 農業技術研究機構 野菜茶業研究所** \\ 松尾喜義・近藤貞昭 \\ (平成15年 5 月27日受理)
}

\section{Composition of Amino Acids in Xylem Sap of Genus Camellia}

\author{
Kunio Okano \\ National Institute of Floricultural Science, National Agricultural Research Organization \\ Kiyoshi Matsuo and Sadaaki Kondo \\ National Institute of Vegetable and Tea Science, National Agricultural Research Organization
}

\section{Summary}

Composition of amino acids in xylem sap of genus Camellia was investigated in order to clarify the physiological significance of theanine accumulated in tea leaves. Xylem sap was collected from intact stems by vacuum suction, and amino acids composition was analyzed by HPLC. Major amino acids founded in section Thea were glutamine, theanine and arginine, while those recognized in sections Camellia, Heterogenea and Paracamellia were glutamine and arginine. Considerable amount of theanine could be detected only in section Thea. Based on the comparison of amino acids composition between xylem sap and new shoots, it was assumed that glutamine in xylem sap would act as a precuesor for further metabolism, while theanine and arginine would play a role of nitrogen translocation, storage and/or ammonium detoxification.

Key words: amino acid, genus Camellia, tea, theanine, xylem sap

1 緒 言

緑茶の旨味を決めるのは，チャ新芽中に多 量に存在する遊離アミノ酸である1。 なかで もテアニン $(\gamma$-glutamylethylamide $)$ は, チャ
に特異的であるとともに量的にも多く，全遊 離アミノ酸の30〜 40\%を占める。テアニンは, 根中でグルタミン酸とエチルアミンからテア ニン合成酵菜によって生成され, 地上部に移 行するが2,3), その生理的意義については不明

* テ305-8519 茨城県つくば市藤本2-1

** $\overline{\mathbf{T}} 428-8501$ 静岡県榛原郡金谷町金谷2769 
な部分が多い。一方, チャ以外のツバキ属植 物（Genus Camellia）の新芽からはテアニン はほとんど検出されない4。これは根のテア ニン合成能力 (エチルアミン合成能力 ${ }^{5}$ ) の差 異に起因すると考えられるが，その直接的な 証明はされていない。

チャでは真空吸引法により木部樹液（導管 液）が比較的容易に採取でき，根における窒 素代謝や樹体の栄養診断の研究に利用されて

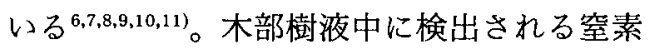
化合物は, 窒素同化の比較的初期過程にある アミノ酸類である7。また，木部樹液の分析 は, 台切り更新にともなう根部の機能変化を 評価する手法としても有効である ${ }^{11}$ 。そこで 本研究では，植物種による根のアミノ酸合成 能力の違いや茶葉への多量のテアニン集積の 生理的意義を明らかにする目的で, 真空吸引 法によりチャ及び近縁ツバキ属植物から木部 樹液を採取し，含まれる遊離アミノ酸を分 析・比較した。

チャは典型的な多肥作物とされているが, その背景にはテアニン等の遊離アミノ酸含量 の高い上級茶の生産志向がある。従って, 茶
園の多肥問題を解決するためにも，チャにお けるテアニン集積の生理的意義を明らかにす ることが重要である。また，化学成分に基づ いたツバキ属植物の分類 ${ }^{4}$ を行う上でも, チャ及びその近縁種の根のアミノ酸合成能力 を比較生理学的に解明することは有意義と考 えられる。

\section{2 材料および方法}

2. 1 調查したツバキ属植物

調查対象としたツバキ属植物の類縁関係を 図 1 に示す。ツバキ属植物の分類には多くの 説が提唱されているが，ここでは最も広く受 け入れられているSealy ${ }^{12)} の$ 分類に従った。植 物材料は, 農林水産省野菜・茶業試験場（金 谷）(現農業技術研究機構野菜茶業研究所)で 保存栽培されている樹齢が10～20年のチャ節 (Section Thea), ツバキ節(Section Camellia), カワリツバキ節(Section Heterogenea)及 びサザンカ節(Section Paracamellia)植物の 中から選定した（図 1)。

チャ節は中国変種 $(C$. sinensis var. sinensis $)$ とアッサム変種 $(C$. sinensis var. as-
（属）

（節）

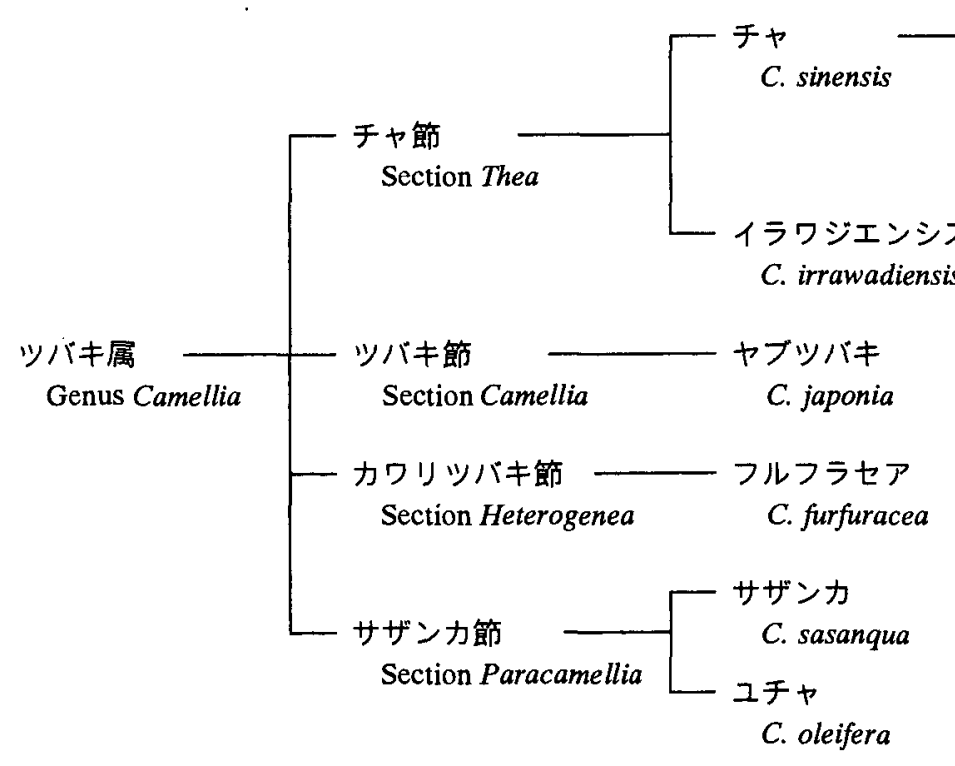

(変種)

(種)

中国変種

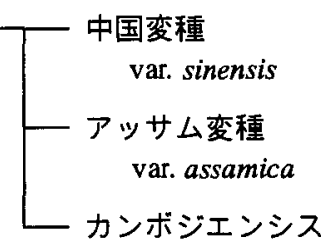

var. cambodiensis

図 1 調查したツバキ属植物の類螕関係（Sealy（1954)の分類による） 
samica)に大別される。そこで, 中国変種の代 表として‘やぶきた’を，またアッサム変種と してインドから導入された'金インド', セイ ロン (スリランカ) から導入された 'ACE 33’，及びマレーシアから導入された 'ABO 11’の 3 係統を選定した。イラワジエンシス (C. irrawadiensis)及びカンボジエンシス $(C$. cambodiensis)は，それぞれビルマ(ミャン マー) 及びカンボジアの固有種であるが, そ の䚻属関係には不明瞭な部分が多い4)。ツバ キ節からはヤブツバキ(C. japonica)を, カワ リッバキ節からはフルフラセア(C. furfuracea)を選定した。カワリツバキ節植物は中国 南部からインドシナ半島にかけて分布してお り，フルフラセアは台湾では台湾山茶とも呼 ばれる4)。サザンカ節からはサザンカ $(C$. sasanqua)とユチャ(C. oleifera $)$ を選定した。 ユチャは長江以南の中国各省において油料作 物として栽培されている。また図 1 には示さ れていないが, チャとヤブツバキの種間雑種 であるチャツバキ(13)についても調查を行った。

\section{2 栽培管理}

チャ節のアッサム変種, カンボジエンシス, イラワジエンシスの 3 種は冬季加温ガラス室内 で, ヤブツバキ, フルフラセア, サザンカ, ユ チャ,チャツバキの 5 種は遺伝資源保存粗場で 保存栽培されている樹種を用いた。これら遺伝 資源植物は春肥のみを施用しているため, 通常 の栽培茶樹と比心゙て約 $1 / 3$ 少肥栽培であった。 一方, チャ節の中国変種( ‘ぶきた') は, 野菜 茶試の施肥基準に従って一般固場で栽培されて いる茶樹の中から選定した。従って, 窒素施肥 量は他のツバキ属植物より $2 \sim 3$ 倍多かった。

\section{2 . 3 木部樹液の採取}

木部樹液の採取は1992年11月上旬の数日間 に行った。採取には, $500 \mathrm{ml}$ のナス型フラスコ と $100 \mathrm{ml}$ の大型試験管を内径 $5 \mathrm{~mm}$ のシリコン チューブで連結した簡易樹液採取装置 ${ }^{11}$ を用 いた。この装置を小型真空ポンプ(MINIVAC PD-52, ヤマト)に接続し, U字型真空計で測 定した真空度が $50 \mathrm{mmHg}$ 以下になるまで吸引
した後, ホフマン型のピンチコックで真空系 の両端を塞ぎ, 真空ポンプから取り外した。

対象となるツバキ属植物より太さ 7-8 $\mathrm{mm}$ の枝 2 本ずつを選び，以下の手順で各枝から 木部樹液を採取した。枝先を剪定ばさみで切 断し，切断部分から $10 \mathrm{~mm}$ 程度の樹皮をナイフ で剥がした。枝先を蒸留水を含ませたガーゼで 拭いた後, 大型試験管側のシリコンチューブ を装着し，ピンチコックを開放にした。樹液採 取装置は午後 5 時に枝先に装着し, 翌朝 9 時 に回収した。大型試験管に採取された樹液は, 液量を測定した後にプラスチック製試験管に

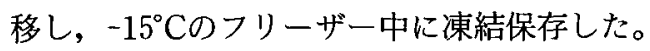

\section{4 新芽の採取}

1993年 5 月上旬に，木部樹液を採取したツ バキ属植物の新芽（生長点と展開中の新葉 2 〜3枚を含む部分）を採取した。新芽はただ ちに蒸熱処理し, $80^{\circ} \mathrm{Cで}$ 通風乾燥した後, 振 動粉䂶器 (TI-100, 平工製作所) で微粉砕し, アミノ酸分析用試料とした。

\section{5 遊離アミノ酸の分析}

冷凍保存した木部樹液は室温下で解凍し, シリンジフィルター $(0.45 \mu \mathrm{m})$ でろ過した 後, 分析に供した。樹液中の遊離アミノ酸濃 度が高い場合には, 蒸留水で適宜希积した。 新芽については, 公定法 ${ }^{14} に$ 従って粉末試料 を熱水抽出し，ろ過した液を分析試料とした。 遊離アミノ酸の分析は, オルトフタルアル デヒド (OPA) 誘導体蛍光発色法による高速 夜体クロマトグラフィーㄴ)で行った。主な分 析条件は以下の通りである。

$$
\text { ポンプ:ウォーターズM-45 }
$$

カラム：資生堂Capcell Pak C18 SG120

$$
(4.6 \times 250 \mathrm{~mm}, 5 \mu \mathrm{m})
$$



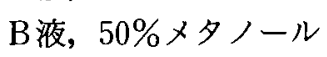

流 量: $1.0 \mathrm{ml} / \mathrm{min}$

グラジェント：A液100\%から60分間かけ て直線的にB液 $100 \% に$ 変化させる。 


\section{3 結果}

簡易樹液採取装置を用いた真空吸引法によ り，夕方から翌朝までの間に 1 本の枝から 30 $\mathrm{ml} \sim 150 \mathrm{ml}$ の樹液が採取できた。しかし，採取 量は植物種あるいは採取日によって大きく変 動した(テータ略)。樹液中の総アミノ酸濃度 は, チャ中国変種（‘やぶきた’）あるいは加 温ガラス室内で栽培されたアッサム変種, イ ラワジエンシスで高く, 遺伝資源保存圊場で 栽培されたツバキ節やサザンカ節植物で低い 傾向が見られた（図2 A)。

9 種類のツバキ属植物から採取された木部 樹液のアミノ酸組成比を表 1 に示す。樹液や 新芽のアミノ酸分析結果はアッサム変種の 3 系統で類似していたので，以下の図表では 'ACE33' の值をアッサム変種の代表值として 示した。チャの中国変種及びアッサム変種で は，グルタミンとテアニンが際立って多く, この 2 種で全体の55-70\%を占めた。チャ節の イラワジエンシスとカンボジエンシスでは, グルタミン, アルギニン, テアニンの 3 種が 主要なアミノ酸であり,これにグルタミン酸, アスパラギン酸が続いた。ツバキ節, カワリ ツバキ節及びサザンカ節植物では, グルタミ
ンとアルギニンの 2 種が主要なアミノ酸で あった。多くの場合, グルタミンが50-70\%を 占めて最も多かったが, サザンカ節のユチャ


図 29 種類のツバキ属植物から採取された木 部樹液(A)及び(B)新芽の総アミノ酸含量

中国種：品種 ‘やぶきた’，

アッサム種：品種 'ACE33' 木部樹液(A)のアミノ酸濃度は 2 本の枝の 平均値を示す。

表 1 チャ及び近縁ツバキ属植物の木部樹液中のアミノ酸組成比（\%)

\begin{tabular}{|c|c|c|c|c|c|c|c|c|c|}
\hline \multirow{2}{*}{ アミノ酸 } & \multicolumn{4}{|c|}{ チ中節 } & \multirow{2}{*}{$\frac{\text { ツバキ節 }}{\text { ヤブツバキ }}$} & \multirow{2}{*}{$\frac{\text { 林ツバ節 }}{\text { フルフラセフ }}$} & \multicolumn{2}{|c|}{ サザンカ節 } & \multirow{2}{*}{$\frac{\text { チャツバキ }}{\text { チャメャブツバ }}$} \\
\hline & 中国変種" & アッサム変種" & イラワジエンシス & カンダシエンンス & & & サザンカ & ユチャ & \\
\hline アスパラギン酸 & 3.4 & 2.8 & 2.9 & 13.6 & 2.0 & 1.6 & 2.6 & 1.6 & 1.5 \\
\hline グルタミン酸 & 5.2 & 6.8 & 9.9 & 9.5 & 9.7 & 6.5 & 3.9 & 3.7 & 7.4 \\
\hline アスパラギン & 0.8 & 1.1 & 1.1 & 0.4 & 0.3 & 1.9 & 0.6 & 0.2 & 0.1 \\
\hline セリン & 0.8 & 1.1 & 0.8 & 2.6 & 0.5 & 1.1 & 1.1 & 0.9 & 0.5 \\
\hline グルタミン & 30.4 & 36.8 & 26.7 & 12.2 & 68.3 & 53.1 & 59.3 & 27.8 & 61.7 \\
\hline アルギニン & 12.7 & 6.7 & 21.6 & 26.5 & 10.7 & 27.9 & 13.9 & 61.0 & 8.1 \\
\hline スレオニン & 1.5 & 1.4 & 2.0 & 1.7 & 0.9 & 0.8 & 2.5 & 0.3 & 0.9 \\
\hline テアニン & 28.5 & 33.3 & 21.2 & 18.1 & N.D. & 0.6 & N.D. & N.D. & 14.3 \\
\hline アラニン & 1.2 & 1.1 & 1.3 & 1.3 & 0.6 & 0.6 & 0.6 & 1.0 & 0.1 \\
\hline その他 ${ }^{3)}$ & 15.5 & 8.9 & 12.5 & 14.1 & 7.0 & 5.9 & 15.5 & 3.5 & 5.4 \\
\hline
\end{tabular}

'品種 ‘やぶきた’， ${ }^{2}$ 系統 'ACE33'

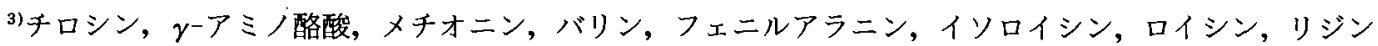
N.D.：今回用いた分析法（HPLC）では検出されなかった。

数字は 2 本の枝の平均値を示す。 
では逆にアルギニンの組成比が $60 \%$ 以上と高 かった。テアニンはチャ節以外の樹液からは 検出されなかったが, ツバキ節のフルフラセ アからは例外的に微量のテアニンが検出され た。なお，チャツバキはチャとヤブツバキの 中間的な值を示し，ヤブツバキと同様にグル 夕ミンが約 $60 \%$ と多かったが，テアニンも チャの半量程度の組成比で検出された。この ように, ツバキ属植物の木部樹液のアミノ酸 組成は比較的単純であり,グルタミン, アル ギニン及びテアニンの 3 種類が主要なアミノ 酸種であった。

木部樹液を採取した翌年の 5 月にサンプリ ングした新芽の遊離アミノ酸組成比を表 2 に 示す。いずれの植物においても，木部樹液よ り新芽の方がアミノ酸組成が多様であった。 チャ節植物ではテアニンが最も多く, 全遊離 アミノ酸の $26-37 \% を$ 上めた。アルギニン,ア スパラギン酸, グルタミン酸, セリン等も比 較的多量に検出されたが，その含量はチャ節 植物の中で一定した傾向が認められなかっ た。ツバキ節，カワリツバキ節，サザンカ節 植物の新芽では，テアニンの代わりに高濃度 のアルギニンの蓄積が認められた。しかしユ チャのみは，木部樹液中に多量のアルギニン が存在したにも関わらず,新芽中にはセリン,
アスパラギン酸，スレオニン，アルギニン等 が分散して存在した。木部樹液の場合と同じ く，チャ節以外の植物の新芽からはテアニン は検出されなかったが, フルフラセアのみは $10 \%$ 程度のテアニンの蓄積が認められた。な お，チャツバキの新芽の遊離アミノ酸の $50 \%$ 以上はアルギニンであったが，かなりの量の テアニンも認められた。

新芽の総アミノ酸含量はチャ節の中国変種 及びチャツバキの 2 種が際立って高く，その 他の植物種はこれらの $1 / 4$ 以下の值であった (図 2 B)。

\section{4 考察}

4. 1 ツバキ属植物におけるテアニンの分布 小西・葛西 ${ }^{2}{ }^{14} \mathrm{CO}_{2}$ の取り込み実験結果か ら，テアニンの合成部位は葉ではなく根であ ることを示した。永田 ${ }^{4}$ も接ぎ木植物の分析 結果から，テアニンの合成部位は根であると している。すなわち，チャ台木に接ぎ木した イラワジエンシスからはテアニンが検出され たが，ツバキ台木に接いだ場合は検出されな かった。種々のツバキ属植物の木部樹液と新 芽のアミノ酸組成を比較した本実験では, 新 芽にテアニンの蓄積が認められた植物では, 例外なく木部樹液中にもテアニンが検出され

表 2 チャ及び近縁ツバキ属植物の新芽のアミノ酸組成比（\%)

\begin{tabular}{|c|c|c|c|c|c|c|c|c|c|}
\hline \multirow{2}{*}{ アミノ酸 } & \multicolumn{4}{|c|}{ チャ節 } & \multicolumn{2}{|c|}{ ツバキ節 カワリツバキ節 } & \multicolumn{2}{|c|}{ サザンカ節 } & \multirow{2}{*}{$\begin{array}{c}\text { チャツバキ } \\
\text { チャメャブバキ }\end{array}$} \\
\hline & 中国変種” & アッサム変和" & イラワジンンシス & カンボシエンシス & ヤブツバキ & フルフラセア & サザンカ & ユチャ & \\
\hline アスパラギン酸 & 9.5 & 15.1 & 28.5 & 15.2 & 15.7 & 12.3 & 12.0 & 16.7 & 6.3 \\
\hline グルタミン酸 & 7.2 & 10.1 & 8.2 & 11.0 & 8.3 & 9.3 & 10.8 & 9.3 & 3.8 \\
\hline アスパラギン & 1.3 & 0.8 & 2.0 & 2.4 & 1.3 & 3.5 & 1.4 & 1.5 & 1.6 \\
\hline セりン & 9.4 & 11.2 & 10.3 & 9.7 & 11.7 & 8.9 & 5.1 & 17.2 & 5.9 \\
\hline グルタミン & 8.7 & 2.3 & 3.1 & 3.1 & 1.3 & 1.8 & 6.5 & 1.9 & 7.8 \\
\hline アルギニン & 19.5 & 3.9 & 7.1 & 13.1 & 33.4 & 34.4 & 47.9 & 10.3 & 51.2 \\
\hline スレオニン & 3.5 & 6.2 & 6.1 & 4.5 & 10.1 & 4.7 & 7.3 & 15.2 & 2.9 \\
\hline 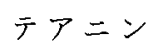 & 31.9 & 36.8 & 25.6 & 36.6 & N.D. & 11.2 & N.D. & N.D. & 15.0 \\
\hline アラニン & 5.8 & 4.3 & 4.1 & 3.1 & 8.3 & 9.4 & 4.7 & 9.3 & 3.9 \\
\hline その 他 ${ }^{3)}$ & 3.2 & 9.3 & 5.0 & 1.3 & 9.9 & 4.5 & 4.3 & 18.6 & 16.6 \\
\hline
\end{tabular}

'品種 ‘やぶきた’, 2)系統 ‘ACE33’

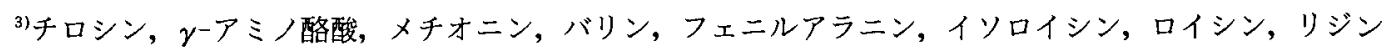
N.D. : 今回用いた分析法 (HPLC) では検出されなかった。 
た。根から地上部へ送られる木部樹液中にテ アニンが検出されたことは，この物質の合成 部位が根であることを示している。

チャの木部樹液を初めて採取・分析した Selvendran ${ }^{61}$ によれば，アッサム変種の樹液 中にはグルタミンとテアニンが特に多く，グ ルタミン酸，アスパラギン酸がこれらに次い だ。保科ら”も中国変種の ‘やぶきた’で類似 の結果を得ている。本実験の結果もこれらの 報告と同様であり，中国変種，アッサム変種 ともに樹液中の主なアミノ酸はグルタミンと テアニンの 2 種であった。この傾向は同じ チャ節のカンボジェンシスとイラワジエンシ スでも同様であった。しかし，これらのチャ 節植物では，グルタミン，テアニンと並んで 多量のアルギニンも検出された。一方，ツバ キ節，カワリツバキ節，サザンカ節植物では, グルタミン及びアルギニンの 2 種類のみが主 要なアミノ酸であり，テアニンは原則として 検出されなかった。しかし，フルフラセアの 木部樹液からは微量のテアニンが検出され， その結果として新芽にもかなりのテアニンの 蓄積が認められた。永田 ${ }^{4}$ も, ツバキ属植物の 新芽に含まれる遊離アミノ酸をHCLP法で分 析し，チャ節植物のみに多量のテアニンの存 在を認めるとともに，フルフラセアからは微 量のテアニンを検出している。

テアニンはチャ節植物を特徵付ける化学成 分であるが，千ャ節以外のツバキ属植物にも 微量のテアニンが存在することが知られてい る。例えば，Tsushidaら ${ }^{15}$ は，ツバキやサザ ンカの挿し木苗や成木からはテアニンは検出 できないが，種子や実生苗からはテアニンが 検出されたことを報告している。小西ら5゙， サザンカの新芽や紐根におけるテアニンの存 在をニンヒドリン発色法により確認してい る。また, 永田 ${ }^{4}$ はフルフラセアだけでなくヒ メサザンカ節植物からも微量のテアニンを検 出している。これらの結果から，チャ節以外 のツバキ属植物でも幼木期にはテアニン合成 能を有するが，その能力は生長に伴って低下 し, 成木期にはHPLC法による検出限界以下 になってしまうものと考えられる。
木部樹液中のアミノ酸組成比は調查した植 物種毎にかなり一定した値が得られた。チャ では，樹液中のアミノ酸組成比の季節変動も 比較的少ないことが報告されている 方，樹液中のアミノ酸濃度については植物種 間で著しい違いが認められた(図 $2 \mathrm{~A}$ )。チャ 木部樹液中のアミノ酸濃度は施肥により急激 に増加する7)とともに，樹齢8)や採取時期 ${ }^{9}$ に よっても変動する。また，同一株内の枝間で もかなりのばらつきが見られる10)。これらの 要因の中で最も影響が大きいのは施肥前歴と 考えられるが，本実験においては中国変種（ ‘やぶきた’）以外のツバキ属植物は厳密な施 肥管理がなされていないので, 施肥前歴の影 響がどの程度あったかを判断することは難し い。その中で，'やぶきた’の樹液や新芽のア ミノ酸濃度が極めて高いのは，施肥量の多さ を反映していると考えられる（図 $2 \mathrm{~A} ， \mathrm{~B}$ )。 しかし，木部樹液中のアミノ酸濃度の変動要 因については，施肥量だけでは説明できない 部分も多いため, 今後, さらに詳細な検討が 必要である。

\section{2 植物体内に蓄積するアミドの生理的 意義}

チャの根に吸収されたアンモニア態窒素 は，まずグルタミンのアミド基に取り込まれ， 次いでグルタミン酸を経てテアニンやアルギ ニンなどに合成される ${ }^{3,7)}$ 。ツバキ属植物の木 部樹液中の主要アミノ酸がグルタミン，テア ニン及びアルギニンであったことは，導管を 通って地上部へ送られる窒素化合物の多くが 根における初期同化産物であることを示して いる。一方, 新芽のアミノ酸組成は木部樹液 のそれとは様相を異にしていた。すなわち， チャ節植物においてはテアニンが，ツバキ節 やサザンカ節植物においてはアルギニンが蓄 積したものの，木部樹液中に多量に存在した グルタミンの新芽への蓄積は認められなかっ た。また，新芽中にはアスパラギン酸，グル 夕ミン酸，セリンなど多様なアミノ酸が検出 された。これらの結果から，根で合成された テアニン及びアルギニンは地上部への移行後 
あまり代謝されずに新芽に蓄積するが，グル タミンは転流過程や新芽中で速やかに代謝さ れ,グルタミン酸やアスパラギン酸等のアミ ノ酸に変化することが推察される。チャの新 芽や緑茎における ${ }^{14} \mathrm{C}$ 標識アミノ酸の代謝実

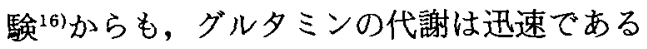
がテアニンの代謝は緩慢なことが確認されて いる。

木部樹液中に含まれる窒素化合物について はツバキ属以外の木本植物でも調べられてお り，リンゴ17)ではアルギニンとアスパラギン が, ウンシュウミカン18)ではアスパラギンと グルタミンが,クヷ'ではアスパラギンが, ス ギ20)やシラカンバ21)ではシトルリンが，また

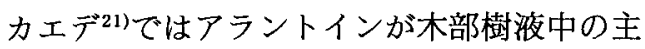
要アミノ酸として報告されている。これらは いずれもアミノ基を 2 個以上持つ窒素化合物 である。一般に，C/N比の低い窒素化合物は 窒素の移動, アンモニアの解毒, 窒素の貯蔵, 窒素化合物の前駆体などの役割を果たすと考 えられている ${ }^{22)}$ 。従って,ツバキ属植物の樹液 中に多く検出されるグルタミンはアミノ酸代 謝の前駆体として，またテアニンやアルギニ ンは窒素の貯蔵形態として機能しているもの と考えられる。チャの場合, 窒素施用量の増 加につれてあるレベルまでは新芽のテアニン 含量が増えるが，過剩施肥下ではテアニンに 代わってアルギニンが大量に蓄積する23)。こ の事実も，テアニンやアルギニンがアンモニ ア態窒素の貯蔵あるいは解毒形態であること を示唆している。

このように多くの木本植物では, 一定量以 上の窒素を吸収すると体内にグルタミン，ア スパラギン，アルギニン等を蓄積する性質が あり，チャの場合にはテアニンという特異な アミドを蓄積する。このため, 窒素施用量の 増加に応じて茶葉中のテアニン含量が増える のである。

茶園の多肥問題は, アミノ酸含量の高い上 級茶の生産を過度に追求した結果といえる。 しかし, 茶樹の吸収能力や解毒能力を超えた 大量施肥は，土墴や水系污染を引き起こすだ けでなく, 茶樹に様々な生理傷害を引き起こ
す23)。また最近では,テアニンは必ずしも茶の 旨味成分の主体ではないとする見解も示され ている ${ }^{24)}$ 。今後は,アミノ酸含量に偏重した品 質評価基準を見直し，旨味成分だけでなく渋 みや香気成分あるいは機能性成分なども含め て, 茶の品質を総合的に把握する評価手法を 開発してゆく必要があろう。

\section{5 摘 要}

チャ新芽に蓄積するテアニンの生理的意義 を明らかにする目的で，9種類のツバキ属植 物から真空吸引法で木部樹液を採取し, 遊離 アミノ酸組成をHPLC法で分析・比較した。 チャ節植物ではグルタミン，テアニン及びア ルギニンの 3 種が主要なアミノ酸であった。 一方，ツバキ節，カワリツバキ節及びサザン 力節植物の木部樹液中の主要なアミノ酸はグ ルタミンとアルギニンの 2 種であり，有意な 量のテアニンは検出できなかった。木部樹液 と新芽の遊離アミノ酸組成の比較から, 木部 樹液中に存在するグルタミンはアミノ酸代謝 の前駆物質として働き，テアニンやアルギニ ンは窒素の移行や貯蔵あるいはアンモニアの 解毒形態として機能しているものと考えられ た。

\section{6 引用 文 献}

1 ）中川致之・阿南豊正・石間紀男 (1981)： 緑茶の味と化学成分との関係, 茶試研報, №.17, 69-123.

2 ）小西茂毅・葛西善三郎(1968)：茶樹に お ける ${ }^{14} \mathrm{CO}_{2}$ からのテアニン生成とその部 位. 茶樹に扔けるテアニンおよびその関連 物質の代謝と制御（第 2 報）。土肥誌 39 ， 439-443.

$3)$ 竹尾忠一(1981): 茶の滋味に関与するテ アニンを中心とした茶樹の窒素代謝. 茶試 研報, No.17, 1-68.

4) 永田忠博(1986)：ツバキ属植物における 葉中の茶有用成分に関する研究。茶試研報, №.21, 59-120.

5 ）小西茂毅・松田隆雄・高橋英一（1969）: テアニンおよびL-Glutamic acid $\gamma$-meth- 
ylamide生成能の植物種間差について，茶 樹におけるテアニンおよびその関連物質の 代謝と制御（第 5 報）。土肥誌40,107-112. 6) Selvendran, R. R.(1970): Changes in the composition of the xylem exudate of tea plants (Camellia sinensis L.) during recovery from pruning. Ann. Bot. 34, 825-833.

7 ）保科次雄・小菅伸郎（1985）：茶樹の根に おける施肥窒素の同化と地上部への転流。 茶研報, No.62，14-17.

8）中村 充 (1988)：茶樹の樹液採取量に及 ほす葉齢，葉層の厚さ，採取時間帯の影響 と樹液組成について。土肥誌，59，96-98.

9）森田明雄 (1991)：樹液による茶樹の栄養 診断．あたらしい農業技術(静岡県農政部) $211,1-12$.

10) Selvendran, R.R. and S. Sabaratnam(1971): Composition of the xylem sap of tea plants (Camellia sinensis L.). Ann. Bot. 35, 679-682.

11）岡野邦夫・酒井慎介（1993）：チャ木部樹 液中のアミノ酸濃度の台切り更新にともな う変化。茶研報, No.77，5-11.

12) Sealy, J. R. (1954): A revision of the genus Camellia. Royal Horticultural Society, London, pp.1-239.

13）武田善行・梁瀬好充・安間 舜（1987）： チャとヤブツバキの F 1 雑種の育成とその 特性について。野茶試研報，B，№.1， $11-21$

14）池ケ谷賢次郎・高柳博次・阿南豊正 （1990）：茶の分析法。茶研報，№.71， 43-74.

15) Tsushida, T. and T. Takeo (1984): Occurrence of theanine in Camellia japonica and Camellia sasanqua seed- lings. Agric. Biol. Chem. 48, 2861-2862. 16）小西茂毅・山路龍一郎（1982）：チャ新芽 に扔けるテアニン,グルタミン，アスパラ ギンの代謝。土肥誌53，241-246。

17）長井晃四郎・福元将志（1983）：リンゴ木 部樹液の遊離アミノ酸及び䌅濃度に対する 季節及び窒素施肥の影響．果樹試報 $\mathrm{C} 10$ ， $35-48$.

18) Kato, T. (1981): Major nitrogen compounds transported in xylem vessels from roots to top in Citrus trees. Physiol. Plant. 52, 275-279.

19) Susuki, T. and K. Kohno(1983): Changes in the nitrogen compounds of xylem sap of mulberry (Morus alba L.) during regrowth after pruning. Ann. Bot. $51,441-448$

20) Mori, T. (1975) : The role of citrulline in nitrogen translocation of Cryptomeria japonica seedlings. J. Jap. For. Soc. 57 , 117-120.

21) Bollard, E. G. (1960) : Transport in the xylem. Ann. Rev. Plant Physiol. 11, 141-166.

22）鈴木米三・増田芳雄 (1978)：植物生化学. 理工学社, 東京, pp.1-401.

23) Okano, K., K. Chutani and K. Matsuo (1997): Suitable level of nitrogen fertilizer for tea (Camellia sinensis L.) plants in relation to growth, photosynthesis, nitrogen uptake and accumulation of free amino acids. Jpn. J. Crop Sci. 66, 279-287.

24）堀江秀樹・氏原ともみ・木幡勝則(2002)： 茶浸出液中の呈味核酸類の分析. 茶研報, №. $93,55-61$. 